\title{
DAYTIME SLEEPINESS AND EPILEPSY: A PILOT STUDY
}

\author{
Received June 10, 2014
}

As was reported, sleep disorders, excessive daytime sleepiness (EDS) in particular, are frequently manifested in epilepsy; insufficient attention has been devoted to this issue in clinical practice in Georgia. We investigated the frequency of EDS cases among healthy individuals and epilepsy patients. A questionnaire study has been conducted using the Epworth Sleepiness Scale (ESS). A group of 251 volunteers (mean age 33.4 years), including 135 subjects without epilepsy and 116 outpatients with this diagnosis (cryptogenic focal/ idiopathic generalized epilepsy without cognitive or brain abnormalities), completed the above questionnaire. The EDS phenomenon was found in $8.9 \%$ of healthy individuals and in $17.2 \%$ of the patients with epilepsy. This problem was more frequent among the epilepsy patients treated by antiepileptic drugs (AEDs). The prevalence of EDS was higher among men suffering from epilepsy, as compared to women with this disease. In the untreated group of the newly diagnosed epilepsy patients, there were more men with EDS than women having this problem. The difference in the EDS occurrence between the two groups of outpatients, treated and untreated with AEDs, was statistically insignificant. Unlike the individuals without epilepsy, a gender difference in terms of the EDS frequency was revealed among the newly diagnosed patients.

\section{Keywords: epilepsy, daytime sleepiness, Georgian population, normalized occurrence,} gender specificity.

\section{INTRODUCTION}

Disturbances in the sleep-wake cycle are often manifested as daytime sleepiness (DS). Excessive DS (EDS) may result from night sleep deprivation or fragmentation and can be a significant reason of decreased alertness, learning and memory problems, and psychomotor impairment [1]. Because EDS is associated with a greater risk of motor vehicle and work accidents, its assessment is of high importance. Excessive DS is a rather common phenomenon, occurring in $0.5-5.0 \%$ of the general populations [2]. Preliminary data on the distribution of sleep-related problems in Georgian youth indicated that EDS is relatively frequently observed in students living in Georgia [3]. This phenomenon is a prominent symptom in various psychiatric and neurological diseases [46]. Interrelation of epilepsy and the sleep mode is a well-known fact [7,8]; EDS and sleep disorders are

\footnotetext{
IIlia State University, Tbilisi, Georgia;

${ }^{2}$ Institute of Neurology and Neuropsychology, Tbilisi, Georgia;

${ }^{3}$ Beritashvili Center of Experimental Biomedicine, Tbilisi, Georgia

Correspondence should be addressed to: L. Maisuradze (e-mail: lia. maisuradze@iliauni.edu.ge or liamais@postmaster.co.uk)
}

frequently manifested in epilepsy [4]. Epilepsy and its treatment may dramatically affect sleep organization and daytime alertness [9]. Several reports documented a high occurrence of clearly manifested EDS cases among the epilepsy patients [4,9-11]. This problem is frequently attributed to the treatment with antiepileptic drugs (AEDs) [5] and is viewed as an adverse effect of the latter [12]. Moreover, it has been reported that treatment with AEDs may be a reason for a higher risk for sleep disorders in patients with epilepsy; AEDs may directly contribute to DS or insomnia or may exacerbate underlying sleep disorders [9].

According to the epidemiological research conducted in 1987-1991, epilepsy occurred in $0.57 \%$ of the general population of Georgia [13]. The more recent study [14] documented that this rate increased up to $0.88 \%$. However, the distribution of DS and/ or other sleep-related problems in patients with or without epilepsy has not been studied in Georgia, though relatively more attention has been devoted to this issue recently $[15,16]$.

Taking into account that recognition of EDS as an important medical problem, in particular linked with the epilepsy treatment, our study aimed at 
investigation/evaluation of the EDS occurrence among people living in Georgia. This pilot study is the first part of a longitudinal research concerning the distribution of sleep disorders in epilepsy patients in Georgia.

\section{METHODS}

The retrospective study has been carried out in order to find associations between epilepsy and EDS. Two hundred fifty-one examined subjects (mean age 33.4 years) were categorized as healthy individuals $(n=135,110$ women and 25 men, mean age \pm s.d., $34.6 \pm 11.9)$ and outpatients with epilepsy $(n=116$, 72 women and 44 men, $31.9 \pm 12.9$ years). The subjects with epilepsy were divided into two subgroups, treated (T) patients with AEDs (86 patients, 56 women and 30 men) and untreated (UT) ones (30 newly diagnosed patients, 16 women and 14 men) who have never taken AEDs before but suffered from epileptic seizures before admission to the Institute of Neurology and Neuropsychology (INN, Tbilisi, Georgia). T-group patients took various AEDs (carbamazepine, valproate, phenobarbital, lamotrigine, or combinational therapy) at admission. Epilepsy was diagnosed or the diagnosis has been proved according to the international classifications $[17,18]$ based on multidisciplinary investigations (consultation of a neurologist/ epileptologist, neuropsychological testing, and EEG recordings) at the INN.

Among 116 consecutive epilepsy outpatients, 95 cases with focal seizures and 21 cases with generalized seizures have been identified. All of them had normal, in general, cognition and did not have any CNS abnormalities on CT/MRI. The subjects without epilepsy were in good general health and served as controls. The following demographic and socioeconomic factors have been considered: age, gender, education, marital status, and employment (night shift workers were excluded).

All participants were asked to fill out the Epworth Sleepiness Scale (ESS) form [19] (following appropriate onwards-backwards English-Georgian translation), the most frequently used subjective evaluation of EDS. The 8-item ESS is widely used as a way of measuring subjective sleepiness in research and clinical practice $[20,21]$. Subjects with the ESS score eleven or more were considered as clinically significant EDS cases.
Associations for categorical variables were examined by the Pearson $\chi^{2}$ test; the Student's $t$ test was used for continuous variables [22]. Data analysis was performed using SPSS statistical software, version 13.0.

\section{RESULTS}

A clear association between the diagnosis of epilepsy and EDS occurrence was found $\left(\chi^{2}=3.91\right.$, df- $1, n=251$, $P=0.048)$. Examination of within-group frequencies showed that about $17.2 \%$ (20 out of 116) of patients with epilepsy experienced EDS, as compared to $8.9 \%$ (12 out of 135) of individuals without epilepsy, i.e., the occurrence of EDS in epilepsy patients was about two times greater than that in healthy subjects.

Among the newly diagnosed patients with epilepsy, who have not been treated with AEDs, EDS was detected in $13.3 \%$ (4 out of 30 cases; the difference between EDS frequencies in patients and control subjects did not reach the significance level).

A considerable difference was found in the prevalence of EDS between UT group-men $(28.6 \%$; 4 out of 14$)$ and healthy men $(4.0 \%$; 1 out of 25 ; $\chi^{2}=4.85$, df- $\left.1, n=116, P=0.047\right)$. None of the women in the UT group had EDS; however, this problem was found in 10\% (11 out of 110) of women without epilepsy.

Considerable intergender differences were observed in the frequency of EDS in epilepsy patients. The prevalence of EDS was much higher in men $(27.3 \%$; 12 out of 44$)$ than in women $(8.3 \%$; 6 out of 72 ; $\chi^{2}=7.50$, df- $\left.1, n=116, P=0.0064\right)$. As was mentioned, in subjects without epilepsy, $10.0 \%$ women (11 out of 110 ) and $4.0 \%$ men ( 1 out of 25 ) had EDS; however, the difference was statistically insignificant. Four out of 30 untreated epilepsy patients $(13.3 \%)$ and 18 out of 86 patients treated with AEDs $(18.6 \%)$ were identified as the individuals having EDS; however, the difference between these two subgroups was not statistically significant.

In the T group, EDS was revealed in $26.7 \%$ ( 8 out of 30 ) of men and $10.7 \%$ (6 out of 56 ) of women (the gender difference did not reach the significance level). There was a nearly similar distribution of EDS in treated and untreated men suffering from epilepsy, $26.7 \%$ ( 8 out of 30 ) and $28.6 \%$ (4 out of 14 ), respectively. 


\section{DISCUSSION}

In this pilot study, we have evaluated the EDS frequency among the healthy individuals and patients with epilepsy living in Georgia, using the ESS [19]. This questionnaire has been proposed as a quick, efficient, and inexpensive measure of the subjective EDS; it is often used for confirmation of EDS in epilepsy patients $[4,10]$. We found that EDS (identified according to ESS score $>10$ ) is about two times more frequent in epilepsy patients than in the individuals free from this pathology. A variety of reasons can result in EDS in healthy subjects; yet, a much greater occurrence of EDS in epilepsy patients shows that this disease clearly correlates with the analyzed phenomena. Although EDS was less frequent among the subjects without epilepsy, as compared to the newly diagnosed untreated epilepsy patients (not taking AEDs), this difference was not statistically significant. This fact might be related to the relatively small number of the newly diagnosed and examined untreated epilepsy patients, who applied to the INN in the course of our investigation.

It is often reported that EDS in epilepsy patients is due to the treatment by AEDs, and these patients possess a higher risk for sleep disorders, as the treatment with these drugs may directly contribute to DS or insomnia [23, 24]. Using the ESS, a widely used and validated subjective measure of DS [19], Malow et al [4] reported that $28 \%$ of 158 surveyed adult epilepsy patients had an elevated score (higher than 10 points). The results of our study agree to a certain extent with the findings of those authors who have indicated a high prevalence of sleep complaints and EDS in epilepsy patients $[4,10,11]$. Thus, this phenomenon in epilepsy is observed in different countries and among different ethnic groups.

Epilepsy outpatients in Georgia, who took AEDs, were more predisposed to EDS than the subjects without epilepsy. Subjective sleepiness was common in both groups (UT and T) of epilepsy patients, but only a slight trend toward elevated frequency of EDS was revealed among the patients treated with AEDs.

The results of our study concerning intergender differences in the prevalence of EDS seem to be especially interesting. In particular, it was noted that EDS was more frequent in men than in women suffering from epilepsy $(P<0.05)$. No significant difference has been observed in the EDS occurrence among the healthy men and women. However, more than one quarter of male subjects in the UT group (taking no AEDs) were identified as having EDS. The analysis of the data on the EDS distribution among the $\mathrm{T}$ group-subjects did not show any gender difference. Our findings on the frequency of EDS in men allow us to state that EDS was less prevalent among men in the control group than among male subjects in the UT or T subgroups $(P<0.05)$. As for the occurrence of EDS among women, no intergroup differences have been found. An interesting finding was that EDS was noticeably more frequent in men compared to women in all investigated groups (control, T, and UT).

Thus, the findings of our study on the occurrence of EDS among Georgian people with and without epilepsy allow us to conclude that EDS is a noticeable medical problem in Georgian epilepsy patients. More research is needed to assess the EDS occurrence among epilepsy patients in relation to the treatment strategy, socio-demographic factors, and a sleep-wake schedule or sleep difficulties. Longitudinal studies have to be carried out to investigate this problem that would allow us to clarify whether EDS is a specific consequence of anti-epileptic therapy, or sleep disorders (insomnia, obstructive sleep apnea, a restless legs-syndrome, etc.) frequently coexist with epilepsy with no dependence on the treatment used.

Acknowledgement. The study was supported by the Georgian State Program "Prevention and Diagnosis of Epilepsy".

The study was carried out in accordance with ethical institutional guidelines and national and international laws and policies. Because of a retrospective pattern of the study, obtaining informed consent from the involved subjects in the course of analysis was not necessary.

The authors, L. M. Maisuradze, L. V. Zhizhiashvili, G. V. Lomidze, and S. V. Kasradze, confirm that they have no conflict of interest with any organization or person that may be related to this study; there was also no conflict of interest in interrelations between the authors.

\section{Л. М. Майсурадзе $e^{1,3}$, Л. В. Жіжіашвілі ${ }^{2}$ Г. Ломідзе ${ }^{2}$, С. В. Касрадзе ${ }^{2}$}

\section{СОНЛИВІСТЬ ВДЕНЬ ТА ЗАХВОРЮВАННЯ НА ЕПІЛЕПСІЮ: ПІЛОТНЕ ДОСЛІДЖЕННЯ}

${ }^{1}$ Державний університет ім. Ілії, Тбілісі, (Грузія)

${ }^{2}$ Інститут неврології та нейропсихології, Тбілісі, (Грузія)

${ }^{3}$ Центр експериментальної медицини ім. І. Бериташвілі, Тбілісі, (Грузія) 
$\mathrm{P}$ е 3 ю м е

Як відомо, розлади сну, зокрема сонливість вдень, часто виявляються при захворюванні на епілепсію; цьому аспекту, проте, приділялося недостатньо уваги. Ми визначали частоту випадків надмірної сонливості вдень (НСВ) у здорових осіб та пацієнтів із епілепсією в Грузії. Дослідження було проведено за допомогою опитування з використанням Епворт-шкали сонливості (ESS). Група 3251 добровольця (середній вік 33.4 року), в котру входили 135 контрольних, не хворих на епілепсію осіб, та 116 пацієнтів із діагностованою криптогенною фокальною/ідіопатичною генералізованою епілепсією без когнітивних розладів та церебральних анормальностей, заповнювали опитувальник ESS. Феномен НСВ був виявлений у 8.9 \% здорових осіб та $17.2 \%$ пацієнтів із епілепсією. Ця проблема зустрічалася частіше серед пацієнтів, що приймали антиепілептичні фармакологічні засоби. Частота випадків НСВ у чоловіків, що страждали на епілепсію, була вищою, ніж така у жінок із подібною патологією. У підгрупі пацієнтів із щойно встановленим діагнозом, котрі не піддавалися антиепілептичній терапії, нормована кількість чоловіків із НСВ була вищою, ніж аналогічний показник у жінок. Різниця частот НСВ у двох підгрупах пацієнтів, котрі приймали або не приймали антиепілептичні засоби, була статистично невірогідною. На відміну від групи контролю, у пацієнтів зі щойно встановленим діагнозом спостерігалася залежність частоти НСВ від статі.

\section{REFERENCES}

1. D. F. Dinges, F. Pack, K. Williams, et al., "Cumulative sleepiness, mood disturbance, and psychomotor vigilance performance decrements during a week of sleep restricted to 4-5 hours per night," Sleep, 20, 267-277 (1997).

2. M. Carscadon, W. C. Dement, M. M. Mitler, et al., "Guidelines for the Multiple Sleep Latency Test (MSLT): a standard measure of sleepiness," Sleep, 9, 519-524 (1986).

3. L. Maisuradze, N. Lortkipanidze, and N. Oniani, "Sleep-wake schedules and subjective sleep- quality of Georgian university students," Sleep Med., 12, Suppl. 1, p. 32 (2011).

4. B. A. Malow, R. J. Bowes, and X. Lin,'Predictors of sleepiness in epilepsy patients," Sleep, 20, 1105-1110 (1997).

5. R. Manni, L. Politini, I. Sartori, et al., "Daytime sleepiness in epilepsy patients: evaluation by means of the Epworth sleepiness scale," J. Neurol., 247, No. 9, 716-717 (2000).

6. R. Khatami, D. Zutter, A. Siegel, et al., "Sleep-wake habits and disorders in a series of 100 adult epilepsy patients- A prospective study," Seizure, 15, No. 5, 299-306 (2006).

7. A. Crespel, M. Baldy-Moulinier, and P. Coubes, "The relationship between sleep and epilepsy in frontal and temporal lobe epilepsies: practical and physiopathologic considerations," Epilepsia, 39, No. 2, 150-157 (1998).

8. B. A. Malow, "The interaction between sleep and epilepsy," Epilepsia, 48, Suppl. 9, 36-38, 2007.

9. B. A. Malow and B. V. Vaughn, "Sleep disorders and epilepsy," in: Managing Epilepsy and Co-Existing Disorders, A. B. Ettinger and O. Devinsky (eds.), Butterworth-Heinemann, Boston (2002), pp. 239-254.

10. J. B. Hoeppner, D. C. Garron, and R. D. Cartwright, "Selfreported sleep disorder symptoms in epilepsy," Epilepsia, 25, 434-437 (1984).

11. B. V. Vaughn, M. T. Miller, O. F. D’Cruz, and J. Messenheimer, "Prevalence of sleep complaints in patients with epilepsy: application of the Epworth sleepiness scale," Sleep Res., 25, 453 (1996).

12. E. Beghi, "Adverse reactions to antiepileptic drugs: a multimember survey of clinical practice," Epilepsia, 27, 323330 (1996).

13. T. Geladze, M. Virsaladze, O. Toidze, et al., "Some epidemiological aspects of Epilepsy in the East Georgia," in: Collected Papers of the Sarajishvili Institute of Clinical and Experimental Neurology [in Russian], Megobari, Tbilisi (1995).

14. G. Lomidze, S. Kasradze, D. Kvernadze, et al., "The prevalence and treatment gap of epilepsy in Tbilisi, Georgia," Epilepsy Res., 98, 123-129 (2012).

15. L. Zhizhiashvili, L. Maisuradze, G. Lomidze, and S. Kasradze, "Prevalence of sleepiness among adults with and without epilepsy in Georgia: Preliminary findings," JSR, 17, Suppl. 1, p. 30 (2008).

16. G. Kuchukhidze, I. Toidze, I. Khatiashvili, L. Maisuradze, et al., "Prevalence of restless legs syndrome in a Georgian primary healthcare setting: a pilot study," Eur. Neurol., 68, 177-180 (2012).

17. "Commission on Classification and terminology of the International League against epilepsy: Proposal for revised classification of epilepsies and epileptic syndromes," Epilepsia, 30, 389-399 (1989).

18. "Commission on Classification and terminology of the International League against epilepsy: Proposal for revised and electrical classification of epileptic seizures," Epilepsia, 22, 489-501 (1981).

19. M. W. Johns, "A new method for measuring daytime sleepiness: the Epworth Sleepiness Scale," Sleep, 14, 540-545 (1991).

20. M. S. Miletin and P. J. Hanly, "Measurement properties of the Epworth Sleepiness Scale," Sleep Med., 4, 195-199 (2003).

21. N. Tachibana and M. Taniguchi, "Why do we continue to use Epworth sleepiness scale?," Sleep. Med., 8, 541-542 (2007).

22. B. R. Kirkwood and J. A. C. Sterne, Essential Medical Statistics (2nd ed.), Blackwell Science, Oxford (2003).

23. A. Declerck and A. Wauquier, "Influence of antiepileptic drugs on sleep patterns," Epilepsy Res. Suppl., 2, 153-163 (1991)

24. P. Wolf, "Influence of antiepileptic drugs on sleep," in: Advances in Epileptology, P. Wolf et al (eds.), Raven Press, New York (1987), pp. 733-737. 